\title{
Methodological Compression in Foreign Language Teaching of Engineering Students
}

Irina V. Bgantseva
Natalya A. Prom
Tamara G. Yovanovich*
Tatyana S. Likhacheva
Olga V. Toporkova
Inna V. Vysotskaya
Natalya V. Alekseenko
Elena A. Litvinova
Department of Foreign Languages, Volgograd State Technical University, Volgograd, Russia.

ARTICLE INFORMATION

Original Research Paper

Received Jan. 2019

Accepted Apr. 2019

\section{Keywords:}

methodological compression, integrated teaching technology, lexico-grammatical mapping, algorithms,

didactic supports

\begin{abstract}
This article describes the potential of categorizing technologies in development of job-oriented communicative competence. The authors introduce a new lingvo-didactic concept of methodological compression and explain its essence as applied to foreign language training of future engineers. The training is implemented within the framework of competence, communicative and cognitive approaches. It works as an efficient way of training intensification achieved through compilation of several methods, techniques and forms of activity while employing various sensory channels. To optimize the structure and content of foreign language training in technical universities the following forms of work are proposed to be incorporated: method of lexico-grammatical mapping, system and structure algorithms, efficient didactic supports and charts. The study showed that methodological compression ensures methodologically competent individualization of knowledge, flexibility of learning process adaptation to cognitive features of engineering students, increased efficiency of development of professional foreign language competence resulting not only in the body of foreign language knowledge, abilities and skills, but also in a set of system and structure algorithms of actions which constitute a certain component in the communicative competence of engineering students.
\end{abstract}

\section{Introduction}

The development of higher education updates the search for new approaches to the organization of joboriented training process including foreign language training. The concept of cognitive and systematizing development in foreign language training involves the consideration of cognitive, activity-oriented and communicative aspects of learners' speech from the point of view of systematizing technologies based on methodological compression. These technologies are based on the search for alternative models of educational systems, development of complex and concise systematizing and summarizing methodological modules viewed in the context of continuous efficient development of leaners' cognitive potential including the paradigm of joboriented foreign language training. 
The current study stemmed from the ongoing contradictions between the needs of modern higher education for cognitive development of learners capable of independent foreign language communication and the lack of theoretical and technological foundation of the concept which provides a solid framework for such development during job-oriented foreign language education at university.

In this respect, it is relevant to develop theoretical lingvo-didactic basic guidelines in order to intensify the process of foreign language training of engineering students. These guidelines could include innovation technologies and methods of material presentation to increase efficiency of foreign language knowledge acquisition and development of communication skills within a limited time allocated by the curriculum for the discipline "Foreign Language" in a non-linguistic university through maximum utilization of learners' abilities.

Currently, the solution for this problem is being searched in widely different directions. The most promising directions are those addressing the problem in a consistent manner, based on a sound methodological basis with its own specific principles. In this context the following principles are the most important - the principle of active and meaningful language acquisition as a means of self-development, self-education and collaboration; consideration of the use of graphic means of cognitive visualization, general logical methods of learning and algorithms, effective cognitive and communicative supports; attention to students' individual typological characteristics, etc. (Bgantseva, 2018).

\section{Literature Review}

The main aim of cognitive education based on the ability to analyze conditions and find a generalized way of interaction with foreign language material is to develop a comprehensive range of mental capabilities and strategies making possible the process of learning and adapting to new communication situations. In the circumstances of such cognitive proficiency, more emphasis is put not on absorbing information but on understanding the internal relations of linguistic concepts and speech constructs under study. In addition, learners are encouraged to interactive research thinking and their mental activity concentration is increased. Under such an approach to teaching conscious and informed discussion involves challenging cognitive work, contributes to the highly effective improvement of mental activity.

One of the ways to ensure a learner-centered approach in professional training is a search for those teaching technologies which would assist individual's self-realization and lead to development of educational products relevant to subjects and fields of study (Baryshova, 2009). In this case the student is the subject of his or her own education and has an opportunity to plan his or her individual learning trajectory, set educational goals, select the content and forms of education, that is, to participate in designing his or her own education. Learning becomes meaningful learning activity only if it is in line with certain characteristics, students aren't focused on the assimilation of the content of training as much as they are focused on exploring the methods of learning activity, on developing their cognitive activity and independence.

Thus, the experience of working in a technical university gained over a long period of time has shown that communicative competence of engineering students is likely to develop more effectively if the following methods are integrated in the structure and contents of the foreign language learning process: method of lexicogrammatical mapping, system and structure algorithms, efficient didactic supports and diagrams. In this case, there should be a systematic monitoring of the level of the main communication skills developed within the framework of methodological compression (Bgantseva, 2012; Brushlinskij, 1983; Buran \& Filyukov, 2015; Khromov et al., 2015; Kunin, 1980).

In response to a perceived need for practical application of the suggested methodological tools it was 
necessary to introduce and methodologically justify a new means and concept providing the basis for cognitive development during the job-oriented foreign language university training. This new concept is methodological compression, i.e. an innovative means to introduce and practice learning material which is professionally relevant to engineering students in order to, eventually, use it effectively in communication.

\section{Method}

This article describes the developed theoretical framework, methods and ways of presenting foreign language material in order to increase the efficiency of its learning within a limited period of time while maximizing cognitive abilities of learners. The main methods are as follows: the method of theoretical analysis of approaches to language and speech learning existing in lingvo-didactics; the method of monitoring receptive and productive speech activity of engineering students in order to identify specifics of speech and language learning; methods of systematization and classification of teaching material while developing typologies of tasks and exercises based on lexico-grammatical cards, algorithms and supports.

\section{Results}

\subsection{Paradigm of methodological compression}

We define methodological compression as a means of intensified training achieved by introducing active foreign language material in a concentrated, yet optimal for meaningful understanding, way. Furthermore, such intensified training is realized through lexico-grammatical mapping, visually summarizing algorithms and charts, efficient supports as well as through compilation of these methods, techniques, forms of activities and sensory channels (visual, auditory, kinesthetic). Individual personality types are certain to be taken into consideration within a particular time or didactic period (lexico-grammatical section, subject, module) (Bgantseva, 2018).

In this case, foreign language material is methodologically compressed both in terms of content (method of lexico-grammatical mapping, efficient algorithms and charts) and strategy (compilation of methods, techniques, forms of activities, activation of several sensory channels at the same time).

The technique of compression impact on selected components of foreign language communication training is often used in language education. For instance, teaching text compression helps to develop foreign language writing skills (Kunin, 1980; Rogova, 1991; Dronova, 2013).

The concept introduced in this study is based on the idea that methodological compression is a means of complete impact on the process of foreign language teaching and has some features of a teaching tool. It is realized in accordance with didactic principles and, eventually, is aimed at achieving the didactic goal enhancing foreign language communication skills. It should be noted that methodological compression can be classified into definite types, for example, according to the degree of compression impact and the object of this impact.

It is also essential that personality types of learners should be taken into consideration because constitutional-psychotypological characteristics of a person define the psychic and behavioral structure of a personality which, in turn, determines how well adaptation, compensatory and motivation mechanisms work in terms of foreign language learning efficiency (Dobrynina, 2004). This is the foundation of the learner-centered approach and genuine individualization of the learning process (Zajtsev, 2013; Sattarova, 2014; Soprantsova, 2013).

Thus, methodologically appropriate individualization of tasks, selection of cognitive strategies taking into 
account psychotypological differences of learners within the framework of learning process simulation based on methodological compression will allow to differentiate exercises in a better way.

Moreover, methodological compression will ensure more flexible adaptation of the learning process to the specifics of development of engineering students' communicative competence. This factor relates to cognitive characteristics of engineering students and the specifics of their cognitive style.

The cognitive style of technical specialists is thought to depend on the dominance of the left hemisphere (Nagornova, 2012), which is responsible for speech. This cognitive style, also named "linguistic", includes certain stylistic parameters: poly-independence, reflectivity, flexibility of gnostic control, high cognitive complexity, etc. Research data in the field of cognitive technologies in education (Dobrynina, 2004; Nagornova, 2012, etc) as well as the authors' extensive experience of teaching at a technical university and observation of a foreign language learning of engineering students confirm the assumption of the prevalence of such a cognitive style among engineering students.

The high level of engineering students' logical operations as well as their other cognitive skills allow to outline the optimal boundaries of the methodological compression by applying system and structure algorithms of actions which constitute one or another component of communicative competence perception and realize in practice willingness and capability to implement communicative partnership and introduce an individually directed model of education.

The process of foreign language knowledge acquisition, which represents the result of learners' active mental activity directed by the teacher, has several stages (Andreeva \& Yanoushek, 1982). The first stage is object perception which is connected with distinguishing this object against the background and identifying its essential characteristics. This perception stage is replaced by the stage of comprehension characterized by detecting the most crucial internal and external subjective connections and relations. The next stage of knowledge creation involves the process of memorizing the identified characteristics and connections by means of multiple perception and fixation. Then the process proceeds to the stage of active reproduction by the learner of perceived and acquired essential characteristics and connections. The process of knowledge acquisition concludes the stage of its transformation and is connected with either incorporation of the acquired knowledge into the structure of the previous experience or with application of this knowledge as a means of constructing or identifying some new knowledge.

Hence, it is in a technical university that the use of lingvo-didactic technologies based on methodological compression in the process of foreign language learning is most effective.

\subsection{Teaching methods in the paradigm of methodological compression}

A teaching method is a means of teaching work where the teacher decides on the types of learning and cognitive activity of learners in order to achieve various didactic objectives aimed at handling training material (Kharlamov, 2003: 103).

Pedagogic experts have developed a reliable classification of teaching methods 1) by source of information (verbal, visual, practical), 2) by nature of didactic purposes and solution of cognitive objectives (methods of oral presentation of material by the teacher, methods of material consolidation, methods of learners' individual work devoted to new learning material acquisition, methods of training activity to apply the acquired knowledge, methods of testing and evaluating knowledge and skills), 3) by method of learning material acquisition (explanatory and illustrative, reproductive, case study, searching, research methods) (Rogova, 1991: 110; 
Kossinskaya, 2013). It is essential for a qualified teacher to possess the above mentioned methods.

In recent years the focus of linguodidactics on the activation of learners' cognitive activity and the increase of their independence has led to the proliferation of those teaching methods which are characterized by combining the features of several methods. These are such methods as methods of encouragement and motivation to study, methods of organization and implementation of cognitive activity, methods of control and self-control of learning and cognitive activity efficiency (Pujman, 2002). Such combined methods better meet new requirements for learning outcomes as well as they are fully consistent with the younger generation's mentality formed under the influence of current conditions in Russia. Furthermore, it is necessary to use specific teaching methods which have appeared in the sphere of foreign language teaching.

Job-oriented training of engineering students in the sphere of foreign languages requires those educational models that should be above all characterized by the logically clear and methodologically transparent linguistic explanatory potential as well as well-focused on the development of communicative competence which enables learners to make use of the received linguistic and cultural knowledge in their future professional activity in the field of advanced engineering on a high international level.

The vocabulary of a foreign language under study is an important target of such modeling. We consider rich professionally relevant vocabulary to constitute a significant part of foreign language communication skills. The knowledge of basic grammar constructions and professional terminology belonging to the sphere of technical concepts is an important prerequisite for the successful development of communicative competence.

Given cognitive specifics and communicative competence of engineering students, the method of lexicogrammatical mapping and the section including system and structure algorithms, efficient didactic supports and diagrams has been developed. At the same time, the development level of the main communication skills should be regularly monitored in the paradigm of the methodological compression (Moreira \& Moreira, 2011; Bgantseva et al., 2017; Bgantseva, 2012).

Lexico-grammatical mapping. Lexico-grammatical maps with different compression degrees of the active learning material serve as a construct of a foreign language educational paradigm based on methodological compression. These maps allow the teacher to regulate the main aspects of foreign language activity - how to directly (speaking and listening comprehension) and indirectly (reading and writing) communicate in a foreign language.

For example, an indicative lexico-grammatical map of the module "Metals and Alloys" can be presented in four sections: I - metals as a basis of the development of civilization; II - characteristics and classifications of metals 1) physical and mechanical properties 2) ferrous and non-ferrous metals; III - alloys; IV - metalloids. Each section includes those active lexico-grammatical constructions which provide for dialogical and monological interaction in a foreign language.

Figure 1. Lexico-grammatical map "Metals and Alloys"

\section{Metal is a basis of civilization}

- to be impossible

-discovery and shaping of the metals

- to imagine life

-the significant event of the period

- is/ are based on 


\section{What is metal?}

a) physical and mechanical properties of Metals and Alloys

- Lomonosov's definition

-a good conductor of heat and electricity

- to hold true

- the ability for

- plastic deformation

- a chemical element

- can be forged

- to be hard, heavy, lustrous, malleable, ductile, tenacious

b)

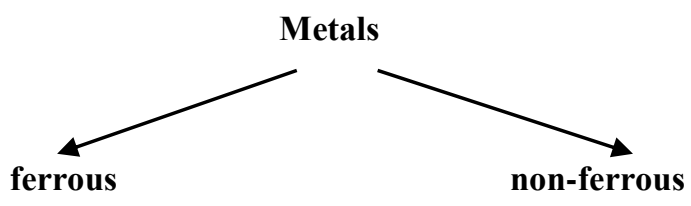

Iron

gold, silver, copper, lead, nickel,

titanium, tungsten, aluminium,

molybdenum, cobalt, tantalum
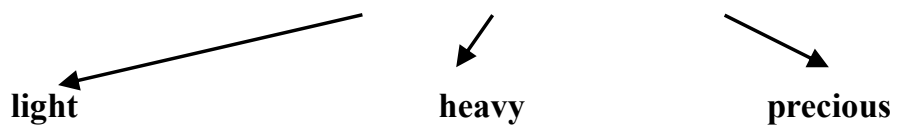

aluminium, magnesium etc.

copper, lead etc. gold, silver, platinum etc.

- have/ has been defined as

- are divided into

\section{Alloys}

- not pure metals

- a mixture with metallic properties

- composed of

- to depend on

- are called

- to posses

- a quality

\section{Metalloid}

-a small group of chemical elements

-including

•carbon, silicon, phosphorus, sulphur and others

-to behave as metals or non-metals

-under various conditions

Learning of lexical units and grammar constructions by means of semantic maps involves a number of stages aimed at developing communication skills: 1) grouping lexical units by a certain thematic aspect; 2) analytical operations of memorizing with the help of relevant tasks using lexico-grammatical mapping; 3) cognitive comprehension of lexical unit meanings in the context of a phrase; 4) strengthening of analysis and thinking processes and enabling correlation of auditory and graphical images of words and visual images of the objects they denote via visualization, i.e. determining not only the meaning but also the function of a word by means of semantic maps which allow to realize associative bonds of lexical units between each other and with the situation.

The development of communicative competence of engineering students based on the method of lexicogrammatical mapping involves the following stages: 
1. Distinguishing and recording communicatively relevant lexical units and most frequently used grammar constructions. It is at this stage that lexical units and grammar constructions are grouped by a certain thematic aspect, belonging to professional terminology and frequency of use. Section content is created on the basis of job-oriented texts or on the existing experience and expertise of students (using a dictionary, if necessary).

2. Practicing communicatively relevant lexical units and most frequently used grammar constructions. Professionally relevant lexical units and grammar constructions are extensively practiced in speech by means of simulation and definition exercises, substitution drills.

3. Independent meaningful use of communicatively relevant lexical units and most frequently used grammar constructions in speech. This stage of lexico-grammatical mapping involves: strengthening and improving vocabulary skills connected with conscious identification and independent naming of objects associated with each other; training the operation of calling up a word from memory, the skill of combining meanings and forming word networks and collocations.

Thus, a map is a diagram / speech pattern / visual support for students and contains a topic-based worksheet which includes essential lexical units and grammar constructions.

Algorithmic method. Since learning the universal ways of using unknown material is becoming an integral part of foreign language education, the method of algorithmic development, or algorithmic method, is of paramount importance as it represents a well-structured visual chart. This method implements another significant construct of the foreign language educational paradigm based on methodological compression (Semyenov, 2006).

Educational psychology defines 'algorithm' as an instruction or prescription which operations and in which succession are to be performed to solve any problem from a variety of similar problems. The main characteristics of algorithms are their determinacy, mass character and resulting quality (Lyapunov. \& Shestopal, 1957). When used, algorithms are guided by the following principles: relevance, usefulness, simplicity and resulting quality (Brushlinskij, 1983; Zueva, 2008; Lyapunov \& Shestopal, 1957).

The efficiency of using algorithms is largely determined by their simplicity and availability, similarity degree of all ways of model description in a basic chain: rule - algorithm - flow-chart for oral discussion graphic recording of mental efforts when motivated.

Thus, algorithmic method requires certainty and structure of activities, unambiguity of prescribed operations eliminating a chance in the choice of actions and is displayed in the form of a chart - graphical representation of an algorithm.

For example, Figure 2 shows the algorithm of appropriate use of a foreign language term.

Figure 2. Algorithm of work with a foreign language term

In a foreign language text, if I come across an unknown term I

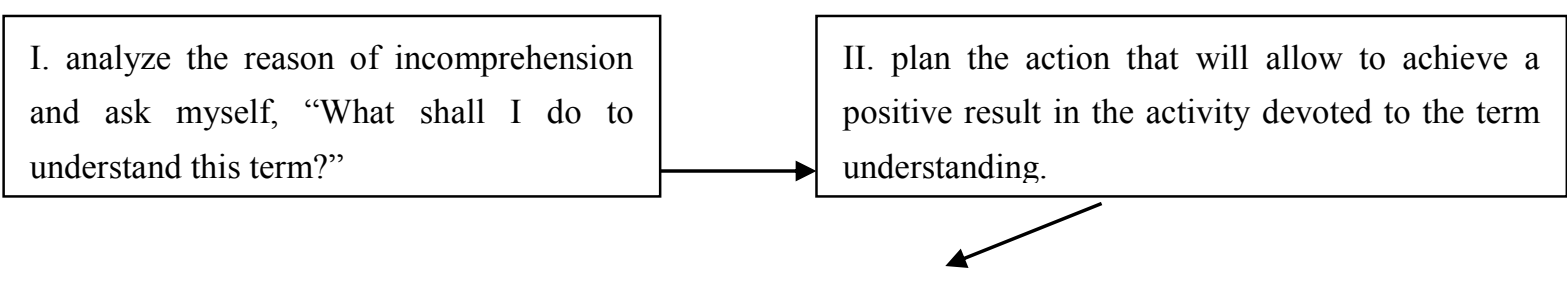


III. use the algorithm of work

with a foreign language term.

read the sentence containing this term and try to guess its meaning from the context

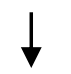

read the passage/supra-phrasal unity/text trying to understand what it is about and guess the meaning of the term

in my head, perform derivational analysis, identify constituent parts of the term recalling the meanings of affixes or remember the history of the language

if the aforementioned actions do not deliver good results, deliberately consult the dictionary and choose a contextually-relevant meaning

write the word down into the dictionary of terminology, make an example sentence with this word and try to remember it

The use of such algorithms contributes to the attainment of several goals. Apart from effective learning of terminology, this course of action helps to develop the habit of analyzing foreign language lexical units mindfully which leads to their long term memory retention and teaches students to avoid mechanical reference to a dictionary or electronic translator.

The algorithmic method can also be used to learn complicated grammar constructions. For example, the theoretical material of the module "Time clauses" can be presented in the form of the following visual support a flow chart (Figure 3).

Figure 3. Flow chart for the module "Time clauses"

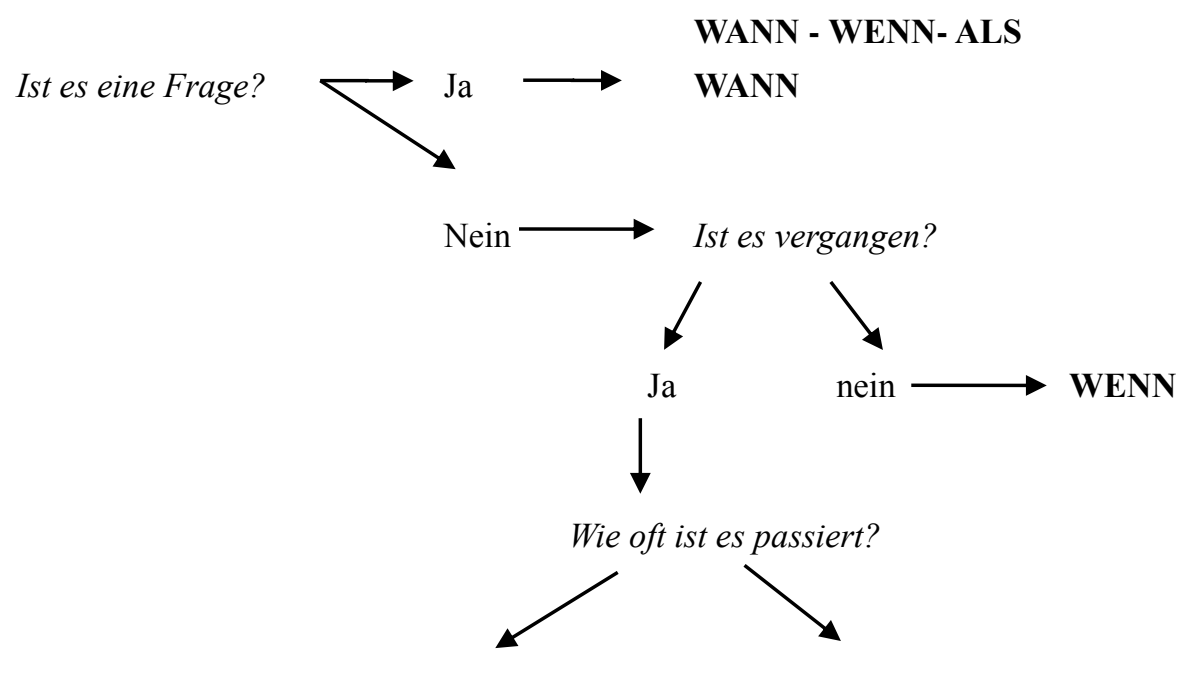

Mehrmals Wenn $\rightarrow$ einmal

Als 
The visual supports, given as an illustrative example, prove an algorithm to be a guideline to develop skills and create concepts. This method helps to systemize and structure students' mental activity as well as gives a sense of purpose and ensures transparency of the learning process.

Algorithmic method in teaching involves three stages. During the preparatory phase, the skills on which the algorithm is based are updated and a new skill is developed. Learners prepare to carry out basic algorithmic operations. The main stage involves the analysis of rules followed by schematic notes of algorithm which facilitate its understanding and learning. As a result of joint step-by-step activities using a flow chart and mandatory detailed commenting specific examples are studied and drills are performed.

The level of independence while using the flow chart increases with each drill performed. Gradually, learners stop using the algorithm directly which shows that they have entered the final stage - the stage of operations compression. Some operations are carried out simultaneously, others instinctively without straining their memory. Abbreviated comments and examples help timely curtail the algorithm which indicates that the skill has been automated.

This method could be efficiently implemented to develop vocabulary skills in order to ensure informed understanding of an unknown word or term, to build grammar skills, that is to work at certain grammar sections, to develop reading skills where the above mentioned method could be used to ensure complete text understanding.

\section{Discussion}

Communication training at a technical university can be improved by utilizing the paradigm of methodological compression put into practice by lexico-grammatical mapping, training algorithms and other efficient didactic supports which are used to present the material in a compressed form.

It is necessary to point out that in foreign language communication teaching the supports, which are considered to be guidelines for speech activity limiting the search zone, promoting thinking and reducing ambiguity and, therefore, speech inaccuracy, serve as verbal guidelines encouraging learners to concentrate their attention on essential lexical units and grammar construction for each thematic cluster.

The function of supports is to transmit certain information in a more or less compressed form. The degree of compression of the general or job-oriented information displayed in a chart depends on the psychotypological characteristics of learners, their cognitive and communicative capabilities.

More advanced learners are provided with supports marked by a maximum degree of compression of lexico-grammatical material where the essential foreign language information is either encoded or graphically represented and serves as an incentive for reflection. The aim of such supports is to manage associations evoked by the information introduced. Meanwhile, less advanced learners are provided with supports marked by a slight degree of compression, i.e. more detailed and containing vocabulary and grammar units sufficient to dwell on the topic.

To determine the content of job-oriented foreign language training it is necessary to perform a thorough selection of the learning material in terms of vocabulary and grammar and carry out its methodological compression. This will ensure students to learn the essential material efficiently, with a sense of purpose and at an adequate level of difficulty. In productive speech activity, utterance patterns are presented in the form of lexico-grammatical maps and efficient supports, in receptive speech activity, charts and algorithms are provided. 
Naturally, the participants of foreign language communication involving didactic supports have different level of language proficiency. However, due to visual supports in the form of conceptual models learners become equally competent in the process of receiving, processing and applying job-oriented foreign language information. On the contrary, communicative competence development without any visual supports can become an unattainable goal.

It should be emphasized that this new learning technology, developed in agreement with the theory of joboriented foreign language communication training of engineering students, is based on the learner-centered cognitive and systemizing methodological compression. This technology is certain not only to ensure high efficiency of all its components individually but also to facilitate potentiation of these effects.

\section{Conclusions}

This paper has illustrated a methodological framework for developing job-oriented foreign language communicative competence of engineering students based on the learner-centered cognitive and systemizing methodological compression.

The concept of methodological compression has been defined as an efficient means of intensified training achieved by compiling several methods, techniques and forms of activity while employing various sensory channels as well as taking into account individual psychotypological characteristics of learners within a certain time and didactic period.

It has been established that foreign language communicative competence of engineering students is built and developed most effectively if the structure and content of the learning process is integrated with such methods as lexico-grammatical mapping, algorithmic method, efficient didactic supports and charts.

The constructs of foreign language educational paradigm based on methodological compression have been developed and their main characteristics and stages in the process of foreign language communication teaching in a technical university have been identified. Lexico-grammatical maps serve as a way to visualize active learning material, they comprise a set of illustrative and schematic supports to efficiently learn and use in communication lexical units and grammar structures. An algorithm has been defined as a well-structured visual chart of sequential steps used to achieve certain communicative aims among a variety of similar problems.

\section{References}

1. Andreeva, G. M. \& Yanoushek, Ya. M. (1982). Obshcheniye i optimizatsiya sovmestnoy

2. deyatelnostiobshcheniye i optimizatsiya sovmestnoy deyatelnosti. Moscow: MSU. 300 p.

3. Baryshova, T. L. (2009). Variativnaya sistema otsenki kachestva

4. obucheniyastudentovtekhnicheskikh spetsialnostey v vuze (extended abstract of Cand. Sci. Dissertation). Moscow. 24 p. Retrived May 18, 2014 from the World Wide Web http://www.dslib.net/profobrazovanie/variativnaja-sistema-ocenki-kachestva-obuchenija-studentov-tehnicheskih-specialnostej.html

5. Bgantseva, I. V., Averina, M. N. \& Solopov, I.N. (2017). Sovershenstvovanie inoyazychnoj kommunikativnoj kompetencii studentov na osnove kognitivno-sistematiziruyushchego podhoda. Yaroslavl Pedagogical Bulletin. No. 1. Pp. 137-143. Retrived December 21, 2017 from the World Wide Web: http://vestnik.yspu.org/releases/2017_1/29.pdf

6. Bgantseva, I. V. (2012). Ispolzovaniye metoda kartirovaniya leksiko-grammaticheskogo

7. materiala s tselyu razvitiya kommunikativnoy kompetentsii studentov sportivnogo profilya. Aktualnyye problemy i sovremennyye tekhnologii prepodavaniya inostrannykh yazykov $\mathrm{v}$ nespetsialnykh vuzakh: 
materialy 5th Vserossiyskoy nauchno-prakticheskoy konferentsii neyazykovykh vuzov na baze VPESA. Voronezh: IPT Nauchnaya kniga. Pp. 80-85.

8. Bgantseva, I. V. (2018). Methodical compression in the system of professionally oriented foreign language communicative training of students majoring in Physical Education (Doctoral Dissertation in Education), Tambov, 2018. Retrived January 19, 2019 from the World Wide Web URL:

9. http://disser.tsutmb.ru/uploaddocuments/2018/bganceva/bganceva_text.pdf.

10. Brushlinskij, A. V. (1983). Psikhologiya myshleniya v problemnom obuchenii. Moscow. 275 p.

11. Buran, A. \& Filyukov, A. (2015). Mind Mapping Technique in Language Learning. Linguistic

12. and Cultural Studies: Traditions and Innovations. LKTI: XVth International Conference, 9-11 November,

Tomsk, Russia: [proceedings]. Vol. 206. Pp. 215-218 https://doi.org/10.1016/j.sbspro.2015.10.010

13. Dobrynina, E. N. (2004). Vliyaniye psikhotipologicheskikh kharakteristik lichnosti na

14. osobennosti izucheniya inostrannogo yazyka (Cand. Sci. Dissertation). Stavropol. 161 p.

15. Dronova, N. A. (2013). Tekhnologiya obucheniya kompressii nauchno-tekhnicheskoy literatury v protsesse prepodavaniya inostrannogo yazyka. Sredneye professionalnoye obrazovaniye. No.10. Pp. 24-27. Retrived September 21, 2017 from the World Wide Web:

16. http://www.portalspo.ru/journal/images/Journals/2013/10_2013.pdf.

17. Kharlamov, I. F. (2003). Pedagogika: kratkij kurs: uchebnoe posobie. Minsk: Vyshehjshaya shkola. 272 p.

18. Khromov, S., Gulayeva, N. A. \& Zelenetskaya, I. S. (2015). An Algorithm for the Integration of

19. Information and Communication Technologies in Teaching Languages for Special Purposes (the Example of Russian as a Foreign Language). Procedia - Social and Behavioral Sciences. Vol. 200. Pp. 224 - 229. https://doi.org/10.1016/j.sbspro.2015.08.056

20. Kossinskaya, E. V. (2013). Metody izucheniya inostrannogo yazyka. Territoriya nauki. No. 1.

21. Pp. 23-28. Retrived September 21, 2017 from the World Wide Web:

22. https://cyberleninka.ru/article/v/metody-izucheniya-inostrannogo-yazyka

23. Kunin, V. S. (1980). Obucheniye monologicheskomu vyskazyvaniyu na osnove logiko-

24. sintaksicheskikh skhem. Problemy kommunikativnogo metoda obucheniya inoyazychnoy rechevoy deyatelnosti. Voronezh. Pp. 15 -19.

25. Lyapunov, A. A. \& Shestopal, G. A. (1957). Ob algoritmicheskom opisanii protsessov

26. upravleniya. Matematicheskoye prosveshcheniye. Iss. 2. Pp.81-95. Retrived September 4, 2015 from the World Wide Web: http://www.mathnet.ru/links/852c9af166d387f456f8f15569a65a38/mp459.pdf

27. Moreira, M. M. \& Moreira, S. M. (2011). Meaningful learning: use of concept maps in foreign language education. Aprendizagem Significativa em Revista/Meaningful Learning Review. Vol. 1(2). Pp. 64-75. Retrived September 18, 2014 from the World Wide Web:

28. http://www.if.ufrgs.br/asr/artigos/Artigo_ID11/v1_n2_a2011.pdf.

29. Nagornova, A. Yu. (2012). Kharakteristika kognitivnoy tekhnologii obucheniya studentov tekhnicheskikh spetsialnostey. Sovremennyye problemy nauki i obrazovaniya. No. 6. Retrived September 15, 2017 from the World Wide Web URL: https://science-education.ru/ru/article/view?id=7645.

30. Pujman, S. A. (2002). Pedagogika. Osnovnyye polozheniya kursa. Minsk: Tetra Systems.

31. Rabinivich, F. M. (1986). K probleme opor pri razvitii ekspressivnykh form rechi. Inostrannyye 32. yazyki v shkole. No. 5. Pp. 20-25.

33. Rogova, G. V. (1991). Metodika obucheniya inostrannym yazykam v sredney shkole. Moscow:

34. Prosveshcheniye. $287 \mathrm{p}$.

35. Sattarova, C. T. (2014). Iz opyta individualizatsii obucheniya inostrannym yazykam. Molodoy 
36. uchenyy. No. 1. Pp. 571-574. Retrived September 15, 2017 from the World Wide Web URL:

37. https://moluch.ru/archive/60/8762/.

38. Semyenov, V. O. (2006). Algoritmizatsiya v obuchenii. Scientific Journal "Transactions of

39. Kremenchuk Mykhailo Ostrohradskyi National University". Iss. 6 (41). Part 1. Retrived September 15, 2017 from the World Wide Web URL: http://zavantag.com/docs/7/index-2111582.html

40. Soprantsova, Yu. S. (2013). Gendernyy podkhod v praktike obucheniya nemetskomu yazyku

41. starshikh shkolnikov (iz lichnogo opyta). Internet-zhurnal Naukovedeniye. No. 3 (16). Retrived September 15, 2017 from the World Wide Web https://cyberleninka.ru/article/n/gendernyy-podhod-v-praktikeobucheniya-nemetskomu-yazyku-starshih-shkolnikov-iz-lichnogo-opyta

42. Zajtsev, A. B. (2013). Individualno-psikhologicheskiye faktory uspeshnosti obucheniya

43. sovremennykh studentov. Bulletin of the South Ural State University. Psychology. No. 2. Vol. 6. Pp. 65-71. Retrived September 15, 2017 from the World Wide Web http://cyberleninka.ru/article/n/individualnopsihologicheskie-faktory-uspeshnosti-obucheniya-sovremennyh-studentov.

44. Zimnyaya, I. A. (1998). Pedagogicheskaya psikhologiya. Moscow: Logos, 380 p.

45. Zueva, I. K. (2008). Vozmozhnosti primeneniya algoritmov v obuchenii samostoyatelnoy rabote

46. po izucheniyu inostrannogo yazyka. Pedagogicheskoye obrazovaniye i nauk. No. 3. Pp. 102-105. Retrived September 15, 2017 from the World Wide Web http://library.ua/m/articles/view/возможности-примененияалгоритмов-в-обучении-самостоятельной-работе-по-изучению-иностранного-языка. 